\title{
An extended technology acceptance model for detecting influencing factors: An empirical investigation
}

\author{
Mohamd Hakkak $^{a^{*}}$, Hojjat Alh Vahdati ${ }^{\mathrm{a}}$ and Vahid Pirdadeh Biranvand ${ }^{\mathrm{b}}$
}

${ }^{a}$ Assistant Proffessor, Management Department, Lorestan University, Khoram Abad, Iran

${ }^{b}$ Master of Art in Executive, Management Department, Lorestan University, Khoram Abad, Iran

CH R O N I C L E

\section{Article history:}

Received June 22, 2013

Received in revised format

28 August 2013

Accepted 27 September 2013

Available online

September 292013

Keywords:

Online banking

Technology acceptance model

Khorramabad

\section{Introduction}

With the rapid growth of Internet technology, online banking has played an important and central role in the e-payment area and it provides an online transaction platform to support many e-commerce applications such as online shopping, online auction, internet stock trading, etc. However, despite the fact that online banking provides many advantages, such as faster transaction speed and lower handling fees (Kalakota \& Robinson, 2003), there are still a large group of customers who refuse to adopt such services due to uncertainty and security concerns (Kuisma et al., 2007; Littler \& Melanthiou, 2006). Therefore, understanding the reasons for this resistance would be useful for bank managers in formulating strategies aimed at increasing online banking use (Lee, 2009). In recent years, a variety of theoretical perspectives have been applied to give some insight of the determinants of Internet banking adoption and applications, including the intention models from social psychology. From this stream of social psychology research, the technology acceptance model (TAM) (Davis,

*Corresponding author. Tel: +98-9122599727

E-mail address: hakkak.m@lu.ac.ir (M. Hakkak)

(C) 2013 Growing Science Ltd. All rights reserved. doi: $10.5267 / \mathrm{j} . \mathrm{ms} 1.2013 .09 .030$ 
1989), an adaptation of theory of reasoned action (TRA) (Fishbein \& Ajzen, 1975) and the theory of planned behavior (Ajzen, 1991) (TPB), are especially well researched intention models that have proven successful to predict technology acceptance behavior (Nasri \& Charfeddine, 2012.;Chau \& Hu, 2001.; Gefen, 2000.; Gefen \& Straub, 2000; Igbaria et al., 1995.; Szajna, 1994). The purposes of this study are to identify and to describe the factors influencing the adoption of Internet banking in Khorramabad, to clarify which factors are more influential in affecting the intention to use Internet banking in Khorramabad and to detect the nature and strength of the relationship among these factors.

The remainder of the paper is set out in six sections. The first section contains a literature review on online banking and information systems acceptance. The second section presents the research model. The third section, the research methodology used in this work. The Fourth section comprises the data analysis and hypotheses testing results. In this section, the data is analyzed using a structural equation modeling. Finally, the results and concluding remarks are given in the last to summarize the contribution of the paper.

\section{Theoretical background}

\subsection{Technology acceptance model}

Al-Somali et al. (2009) provided a comprehensive review of the technology acceptance model (TAM) and reported that users' attitude towards the acceptance of a new information system (IS) could influence on its success (Succi \& Walter, 1999; Davis et al., 1989; Venkatesh \& Davis, 1996). Researchers have been trying to find factors influencing individual's acceptance of information technology (IT) to enhance its usage. Several theoretical models have been proposed that have their roots in ISs, psychology and sociology (Venkatesh et al., 2003). The current study proposes the application of the technology acceptance model (TAM) to capture factors, which have significant impact on the acceptance of online banking. TAM as illustrated in Fig. 1 is one of the most popular models for studying IS acceptance (Al-Gahtani, 2001; Venkatesh \& Davis, 1996; Davis, 1989). TAM posits that two particular beliefs, perceived usefulness (PU) and perceived ease of use (PEOU) are the main determinants of the attitudes (AT) towards implementing a new technology. PU concerns the degree in which a person believes that using a particular system would enhance his or her job performance; while PEOU is defined as the degree in which a person believes that using a particular system would be free of effort (Davis, 1989; Davis et al., 1989). These two beliefs create a favorable behavioral intention (BI) toward using IT that consequently affects its self-reported implementation (Davis et al., 1989). Moreover, TAM postulates that BI is viewed as being jointly determined by the person's attitude towards using system (AT) and PU (Davis et al., 1989).

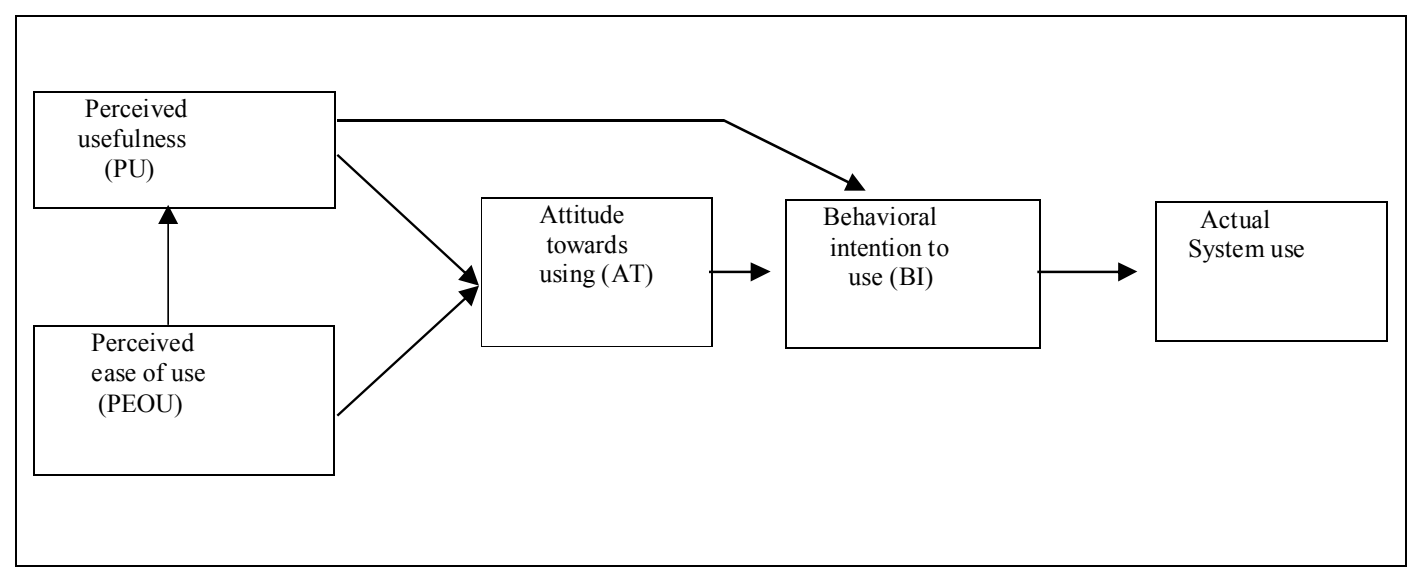

Fig. 1. TAM model (Davis et al., 1989) 


\subsection{Factors influencing online banking acceptance}

Many factors are observed to influence the acceptance of online banking and it is essential to carefully consider these issues.

\subsubsection{Quality of the Internet connection}

The key characteristics of a web site are normally categorized into either content or design (Huizingh, 2000). Content refers to the information offered in the web site. The contents play important roles in influencing the behaviors of consumers. Thus, a lot of studies have selected content (or information content) as a measurement of web site quality (Ranganathan \& Ganapathy, 2002). Although originally online banking focused on the function that performs bank transactions in Internet, most online banking web sites now provide a variety of information areas such as investment, real estate, and personal financial planning information. The information content of online banking may therefore have a positive influence on customers' satisfaction (Yoon, 2010).

\subsubsection{Awareness of services and its benefits}

According to Sathye (1999) the use of online banking services is quite a new experience for many customers and low awareness of online banking is a critical factor in causing customers not to adopt online banking. In his study of Australian customers, Sathye (1999) reported that customers were not aware about the benefits, advantages and disadvantages associated with online banking. This is also consistent with Howcroft et al. (2002), confirming that lack of awareness of online banking services and its benefits are believed to be the main reasons for consumers' reluctance to apply the online banking services offered by banks (Al-Somali et al., 2009).

\subsubsection{Trust}

Alsajjan and Dennis (2010) provided a comprehensive review of the many definition of customer trust. Some of the definition include: Trust is at the heart of all kinds of relationships (Morgan \& Hunt, 1994). Definitions and conceptualization vary with disciplines, such that psychologists view trust as a personal trait, sociologists consider it a social construct, and economists see it as an economic choice mechanism (McKnight \& Chervany, 2002).

In the social psychology realm, Rousseau et al. (1998) define trust as "perceptions about others' attributes and a related willingness to become vulnerable to others." In this sense, consumers might not use e-commerce because they do not trust in Internet businesses (Grewal et al., 2004). With great trust, people can resolve their uncertainty regarding the motives, intentions and prospective actions of others on whom they depend (Kramer, 1999), as well as save money and effort, because trust reduces monitoring and legal contract costs (Fortin et al., 2002).

The lack of trust in online transactions and Web vendors thus represents an important obstacle to the market penetration of e-channels (Liu et al., 2004). Moreover, recent studies indicate that trust had a critical influence on users' willingness to engage in online exchanges of money and sensitive personal information (Friedman et al., 2000).

\subsubsection{Social influence}

Venkatesh and Morris (2000) confirm that social influence plays an important role in determining the acceptance and usage behaviour of adopters of new ITs. In Taylor and Todd's(1995) study, social influences were equivalent to subjective norm and defined as other people's opinion, superior influence, and peer influence. Furthermore, customers may have unfavorable or favorable perceptions 
towards online banking use because of the perceptions of a family member, acquaintances or peers influence. In a similar vein, Davis et al.(1989) believed that in some circumstances people might use a technology to comply with others' mandates rather than their own feelings and beliefs (Al-Somali et al., 2009)

\subsubsection{Resistance to change}

The issue of customers' resistance to change from traditional ways of conducting banking activities to online banking has received considerable attention in the literature (e.g. Sathye, 1999; Wallis, 1997). Generally, unless such a need is accomplished, customers may not be prepared to change from the present ways of operating. Daniel (1999) reported in his study that there was a high level of customers' inertia in changing their established banking activities to online banking (Al-Somali et al., 2009).

\subsubsection{Computer self-efficacy}

In general, prior research has recommended a positive relationship between experience with computing technology and computer usage (Agarwal \& Prasad, 1999; Harrison \& Rainer, 1992; Levin \& Gordon, 1989). Computer self-efficacy is defined as the judgment of one's ability to use a computer (Nasri \& Charfeddine, 2012; Compeau \& Higgins, 1995), self-efficiency (Davis et al., 1989) and Wang et al. (2003) reported that "computer self-efficacy" and "perceived ease of use" are correlated. Polatoglu and Ekin (2001) implied that customers, who are familiar with the Internet and e-mail, should not find Internet banking to be complex. Based on the theoretical and empirical support from the IS literature, it can be concluded that the stronger a person's self-efficacy beliefs, the more likely he or she tries to achieve the required outcome (Al-Somali et al., 2009).

\subsubsection{Demographics characteristic}

The review of the literature concerning online banking user reveals that a typical user can be classified as a highly educated, relatively young and wealthy person with a good knowledge of computers and especially the Internet (Karjaluoto et al., 2002). Many studies have suggested that demographic factors influence heavily on consumer attitudes and behavior regarding online banking (Alagheband, 2006; Sathye, 1999; Lai \& Li, 2005; Lassar et al., 2005; Eastin, 2002; Lee \& Lee, 2001; Burke, 2002). Sathye (1999) indicated that young, educated and wealthy consumers were among those most likely to adapt online banking in Australia (Al-Somali et al., 2009).

\section{Research model}

Drawing upon the earlier discussion based on the theoretical background, this study investigated the determinants of customer attitudes towards online banking acceptance in Khorramabad using an extended TAM taking into account the effect of a few additional important control variables (e.g. the quality of Internet connection, awareness of online banking and its benefits, social influence, computer-related self-efficacy, trust, resistance to change and demographic characteristic).

PEOU and PU influence an individual's attitude towards using online banking; in turn, attitude will influence the intention to use online banking services and therefore influence the actual use of online banking. Actual use will be predicted by individual's adoption intention (AI). The extended TAM used in this study is illustrated in Fig. 2. 


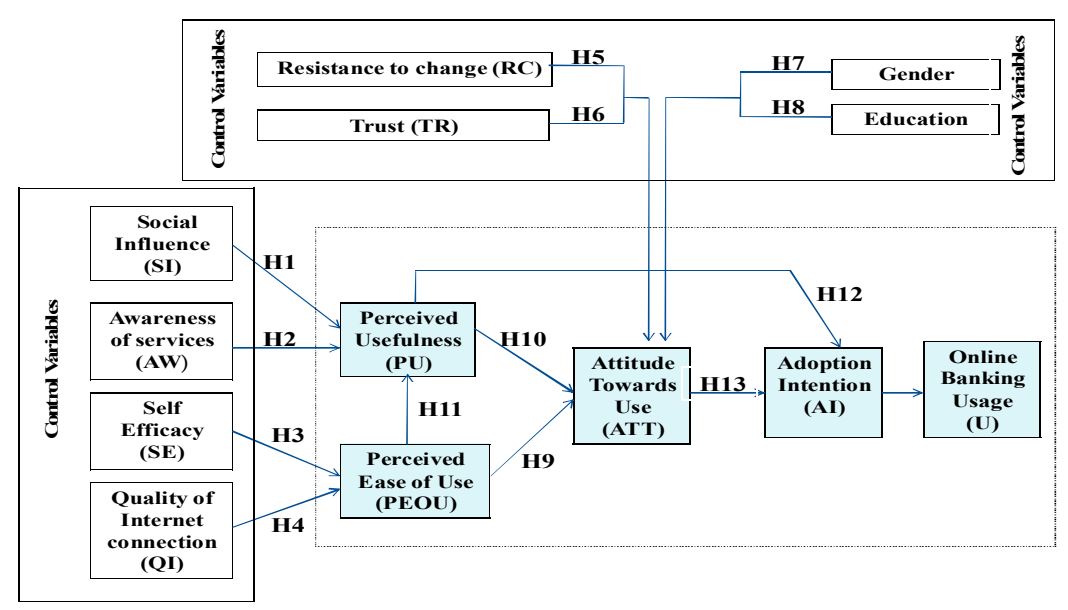

Fig. 2. Proposed research model— the extended TAM

\subsection{Research hypotheses}

$\mathrm{H}_{1}$ : Social influence has a positive impact on customer's perceived usefulness.

$\mathrm{H}_{2}$ : Awareness of services and its benefits has a positive impact on customer's perceived usefulness.

$\mathrm{H}_{3}$ : Higher computer self-efficacy has a positive impact on customer's perceived ease of use.

$\mathrm{H}_{4}$ : Quality of the Internet connection has a positive impact on customer's perceived ease of use.

$\mathrm{H}_{5}$ : Resistance to change has significant impact on customer's attitude towards using online banking.

$\mathrm{H}_{6}$ :Customer's trust in online banking site has a positive impact on his/her attitude towards using online banking.

$\mathrm{H}_{7}$ : Gender has a significant impact on customer's attitude towards using online banking. Males are more likely to adopt online banking.

$\mathrm{H}_{8}$ : Education has a positive impact on customer's attitude towards using online banking.

$\mathrm{H}_{9}$ : Customer's perceived ease of use has a positive impact on his/her attitude towards using online banking.

$\mathrm{H}_{10}$ : Customer's perceived usefulness has a positive impact on his/her attitude towards using online banking.

$\mathrm{H}_{11}$ : Customer's perceived ease of use has a positive impact on his/her perceived usefulness of online banking

$\mathrm{H}_{12}$ : Customer's perceived usefulness has a positive impact on his/her intention to use online banking. $\mathrm{H}_{13}$ : Customer's attitude towards using online banking has a positive impact on his/her intention to use it.

\section{Research methodology}

The survey method was used for collecting the data to test the hypotheses. A sample of 210 people was randomly chosen from the Customers of Tejarat Banks in Khorramabad. These people worked in different organizations and in different industries. All participants were bank customers selected randomly from universities, companies, Internet cafe's. Direct delivery of the survey questionnaire to participants was preferred as opposed to using online or postal surveys. Measurement items used in this study were adapted from previously validated measures or were developed on the base of a literature review or were derived from thorough consultation with IS experts to ensure their reliability and validity. Moreover, a five-point Likert scale ranging from (1) 'strongly disagree' to (5) 'strongly agree' were used to assess responses. A pilot test of the measures was conducted on a representative sample of 20 people randomly chosen and questionnaire statements were modified based on the results of the pilot test. The final questionnaire items used to measure each construct are presented in Table 1. To test this hypotheses, LISREL software was used based on structural equation modeling (SEM), and it was applied to test the measurement model to determine the internal consistency reliability and construct validity of the multiple items scales used. Fig. 3 demonstrates details of the surveyed people. 


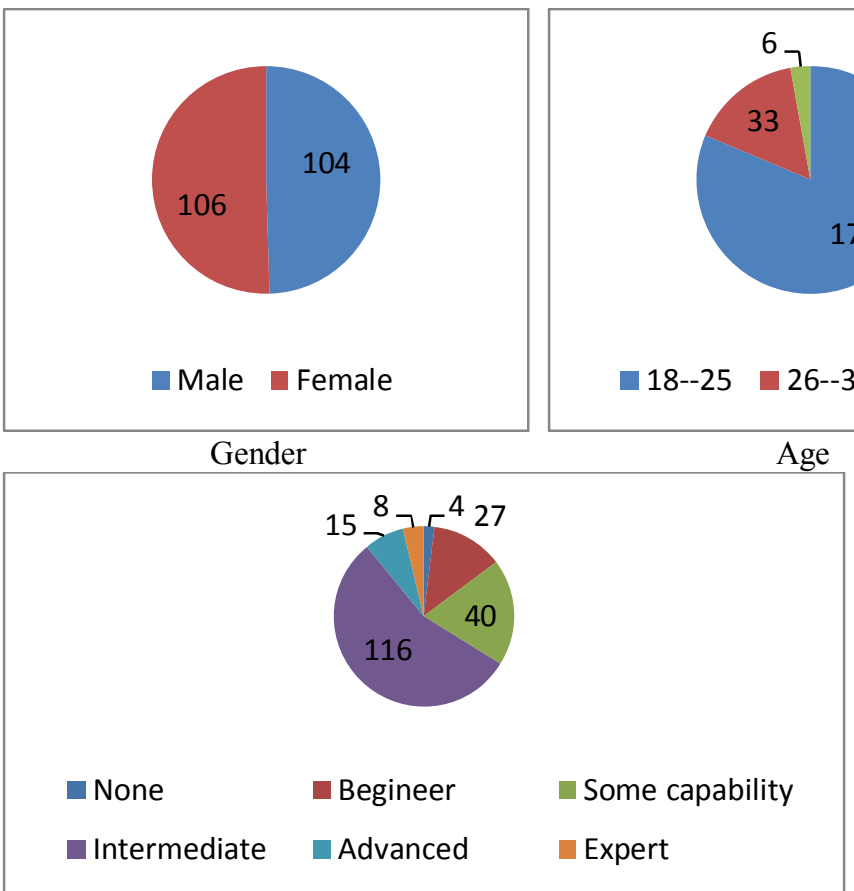

Computer background

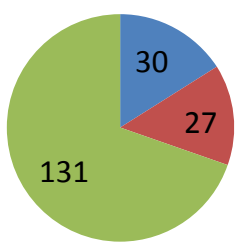

$12 \square 16-18$

Fig. 3. Personal characteristics of online bank users

Table 1

Psychometric properties of the constructs

\begin{tabular}{|c|c|c|c|c|c|}
\hline Constructs & Measures & Loading & $\begin{array}{c}\text { t- } \\
\text { Value } \\
\end{array}$ & $(\alpha)$ & $(\mathrm{AVE})$ \\
\hline \multirow{4}{*}{$\begin{array}{l}\text { Quality of } \\
\text { Internet } \\
\text { Connection } \\
\text { (QI) }\end{array}$} & QI1=My access to the Internet is easy. & 0.54 & 7.14 & \multirow[t]{4}{*}{0.68} & \multirow[t]{4}{*}{0.37} \\
\hline & QI2=The Internet enables to handle my online financial transactions, accurately. & 0.73 & 9.91 & & \\
\hline & QI3=Using the Internet for handling online financial transactions is efficient. & 0.59 & 7.78 & & \\
\hline & QI4=The Internet enables customers to access the bank's website & 0.54 & 7.13 & & \\
\hline \multirow{3}{*}{$\begin{array}{c}\text { Awareness } \\
\text { of services } \\
\text { (AW) }\end{array}$} & AW1=I receive enough information about online banking services. & 0.73 & 11.14 & \multirow[t]{3}{*}{0.82} & \multirow[t]{3}{*}{0.62} \\
\hline & $A W 2=I$ receive enough information about the benefits of online banking. & 0.90 & 14.33 & & \\
\hline & AW3=I receive enough information of using online banking. & 0.72 & 10.96 & & \\
\hline \multirow{4}{*}{$\begin{array}{l}\text { Perceived } \\
\text { usefulness } \\
\quad(\mathrm{PU})\end{array}$} & PU1=Online banking enables me to accomplish banking activities more quickly. & 0.69 & 9.91 & \multirow[t]{4}{*}{0.74} & \multirow[t]{4}{*}{0.44} \\
\hline & PU2=Online banking enables me to improve Performance of utilizing banking services. & 0.75 & 10.98 & & \\
\hline & PU3=Online banking enables me to accomplish more banking activities. & 0.63 & 8.88 & & \\
\hline & PU4=Online banking gives me greater control over financial banking activities. & 0.56 & 7.81 & & \\
\hline \multirow{3}{*}{$\begin{array}{l}\text { Perceived } \\
\text { ease of use } \\
\text { (PEOU) }\end{array}$} & PEOU1= Learning to use online banking will be or has been easy. & 0.70 & 9.73 & \multirow[t]{3}{*}{0.74} & \multirow[t]{3}{*}{0.51} \\
\hline & PEOU2 $=\mathrm{I}$ expect to become or I am already skilled at using online banking. & 0.56 & 7.76 & & \\
\hline & PEOU3 =Overall, I expect online banking will be easy for me to use. & 0.86 & 11.69 & & \\
\hline \multirow{3}{*}{$\begin{array}{l}\text { Attitude } \\
\text { towards use } \\
\text { (ATT) }\end{array}$} & ATT1=Online banking development will support customers. & 0.58 & 7.88 & \multirow[t]{3}{*}{0.58} & \multirow[t]{3}{*}{0.35} \\
\hline & ATT2=I will encourage the use of online banking among my colleagues. & 0.56 & 7.49 & & \\
\hline & ATT3=Overall, the attitude towards online banking usage is positi & 0.62 & 8.43 & & \\
\hline \multirow{2}{*}{$\begin{array}{c}\text { Behavioral } \\
\text { intention to } \\
\text { use (AI) }\end{array}$} & AI1=I will use online banking on regular basis in the future. & 0.64 & 8.14 & \multirow[t]{2}{*}{0.66} & \multirow[t]{2}{*}{0.50} \\
\hline & $\begin{array}{l}\mathrm{AI} 2=\mathrm{I} \text { expect my use of online banking for handling my financial transactions to } \\
\text { continue in the future. }\end{array}$ & 0.77 & 9.34 & & \\
\hline \multirow[t]{5}{*}{ Trust (TR) } & TR1=The online banking site is trust worthy. & 0.75 & 11.83 & \multirow[t]{5}{*}{0.84} & \multirow[t]{5}{*}{0.52} \\
\hline & TR2 $=$ I trust in the benefits of the decisions of the online banking site. & 0.74 & 11.78 & & \\
\hline & TR3=The online banking site keeps its promises and commitments. & 0.75 & 11.95 & & \\
\hline & TR4=The online banking site keeps customers' best interest in mind. & 0.57 & 8.38 & & \\
\hline & TR5=I trust my bank’s online banking site. & 0.79 & 12.68 & & \\
\hline \multirow{2}{*}{$\begin{array}{l}\text { Self- } \\
\text { efficacy } \\
\text { (SE) }\end{array}$} & SE1=I conduct online banking Transactions and I call someone for help if I am in trouble. & 1.00 & 20.38 & \multirow[t]{2}{*}{1.00} & \multirow[t]{2}{*}{1.00} \\
\hline & $\begin{array}{l}\text { SE2 }=\text { I am confident of using online banking system even if I have never used such a system } \\
\text { before. }\end{array}$ & 1.00 & 20.38 & & \\
\hline \multirow{2}{*}{$\begin{array}{l}\text { Social } \\
\text { influence } \\
\text { (SI) }\end{array}$} & SI1=When trying new technology, I trust my own. & 0.75 & 5.94 & \multirow[t]{2}{*}{0.59} & \multirow[t]{2}{*}{0.44} \\
\hline & SI2=When trying new technology, I use advice others. & 0.56 & 5.35 & & \\
\hline \multirow{3}{*}{$\begin{array}{l}\text { Resistance } \\
\text { to change } \\
\text { (RC) }\end{array}$} & $\mathrm{RC} 1=\mathrm{I}$ am interested to hear about new technological developments. & 0.67 & 9.30 & \multirow[t]{3}{*}{0.71} & \multirow[t]{3}{*}{0.49} \\
\hline & RC2=Technological developments have enhanced our lives. & 0.82 & 11.17 & & \\
\hline & $\begin{array}{l}\mathrm{RC} 3=\mathrm{I} \text { feel comfortable in changing and using online banking services for my } \\
\text { financial activities. }\end{array}$ & 0.60 & 8.20 & & \\
\hline
\end{tabular}




\section{Data analysis}

\subsection{Analysis of the measurement model}

Cronbach's alpha scores shown in Table 1 indicate that each construct exhibit strong internal reliability. Convergent validity was assessed based on the criteria that the indicator's estimated coefficient was significant on its posited underlying construct factor All indicator factor loading $(\lambda)$ should be significant and exceed 0.5 and the results of Table 2 indicate that, Inter-Item Correlation Matrix of the each dimension of the scale was positively significant.

Table 2

Correlation Matrix

\begin{tabular}{|c|c|c|c|c|c|c|c|c|c|}
\hline Construct & QI & SE & PEOU & $\mathrm{AW}$ & $\mathrm{PU}$ & $\mathrm{RC}$ & TR & ATT & $\mathrm{AI}$ \\
\hline QI & 1.000 & & & & & & & & \\
\hline $\mathrm{SE}$ & 0.383 & 1.000 & & & & & & & \\
\hline PEOU & 0.445 & 0.341 & 1.000 & & & & & & \\
\hline AW & 0.510 & 0.372 & 0.584 & 1.000 & & & & & \\
\hline SI & 0.391 & 0.410 & 0.263 & 0.224 & 1.000 & & & & \\
\hline PU & 0.472 & 0.196 & 0.296 & 0.331 & 0.352 & 1.000 & & & \\
\hline $\mathrm{RC}$ & -0.385 & -0.451 & -0.199 & -0.279 & -0.497 & -0.427 & 1.000 & & \\
\hline TR & 0.315 & 0.384 & 0.270 & 0.430 & 0.495 & 0.375 & -0.395 & 1.000 & \\
\hline ATT & 0.417 & 0.302 & 0.433 & 0.372 & 0.431 & 0.482 & -0.401 & 0.341 & 1.000 \\
\hline AI & 0.437 & 0.324 & 0.410 & 0.321 & 0.370 & 0.480 & -0.450 & 0.239 & $0.719 \quad 1.000$ \\
\hline
\end{tabular}

\subsection{Examination of research hypotheses}

This section discusses the results relative to the structural model and the hypothesis formed for each construct (Table 3).

Table 3

Assessment of the structural model

\begin{tabular}{|c|c|c|c|c|c|}
\hline No. $\quad$ Hypothesis path & $\mathrm{R}^{2}$ & Path coefficient $(\beta)$ & t-Value & Sig & Supported? \\
\hline H1 $\quad$ SI $\rightarrow$ PU & 0.1849 & 0.43 & 4.17 & 0.000 & yes \\
\hline $\mathrm{H} 2 \quad \mathrm{AW} \rightarrow \quad \mathrm{PU}$ & 0.1369 & 0.37 & 4.13 & 0.000 & yes \\
\hline H3 $\mathrm{SE} \rightarrow$ & 0.0324 & 0.18 & 2.29 & 0.000 & yes \\
\hline $\mathrm{H} 4 \mathrm{QI} \rightarrow$ PEOU & 0.3364 & 0.58 & 5.89 & 0.000 & yes \\
\hline H5 $\mathrm{RC} \rightarrow$ & 0.2601 & -0.51 & -4.50 & 0.000 & yes \\
\hline H6 $\mathrm{TR} \rightarrow$ ATT & 0.1225 & 0.35 & 3.60 & 0.000 & yes \\
\hline Gender $\rightarrow$ ATT & 0.0025 & 0.05 & 1.14 & 0.371 & No \\
\hline Education $\rightarrow$ ATT & 0.0025 & 0.05 & 0.80 & 0.385 & No \\
\hline H9 $\mathrm{PU} \rightarrow$ ATT & 0.3481 & 0.59 & 5.53 & 0.000 & yes \\
\hline H10 PEOU $\rightarrow$ ATT & 0.3136 & 0.56 & 5.49 & 0.000 & yes \\
\hline $\mathrm{H} 11 \mathrm{PEOU} \rightarrow \mathrm{PU}$ & 0.1225 & 0.35 & 3.85 & 0.000 & yes \\
\hline $\mathrm{H} 12 \mathrm{PU} \quad \rightarrow \mathrm{AI}$ & 0.4624 & 0.68 & 6.23 & 0.000 & yes \\
\hline H13 ATT $\rightarrow$ AI & 0.9409 & 0.97 & 8.69 & 0.000 & yes \\
\hline
\end{tabular}

The structural model can be assessed by examining the path coefficients beta weight $(\beta)$, which illustrates how strong the relationships between the dependent is and independent variables and $\mathrm{R}^{2}$ show the predictive power of the model, and the values should be interpreted in the same way as $\mathrm{R}^{2}$ in a regression analysis. There are 11 variables with significant statistical support. It was found that social influence and awareness of online banking services have significant effects on PU. Both paths had positive effects, with path coefficients of 0.43 and 0.37 , respectively, meaning that Hypotheses 1 and 2 were supported. Self-efficacy (SE) and quality of Internet connection did have significant effects on PEOU. These two factors had positive path coefficients of 0.18 and 0.58 meaning that Hypotheses 3 and 4 were also supported. Pu and Peou influenced customer attitudes towards using online banking, supporting Hypotheses 9 and 10. These factors had positive path coefficients 0.59 and 0.56, respectively. As suggested by Hypotheses 5 and 6, resistances to change, and trust 
significantly impact customer attitudes towards using online banking, with path coefficients -0.51 and 0.35 , respectively. Surprisingly, gender and education had no effect on attitudes towards use, as indicated by the two non-significant, that Hypotheses 7, and 8 were not supported. Moreover, both Hypotheses 12 and 13, which suggest that PU and attitude towards using have a significant positive influence on AI were supported with positive path coefficients 0.68 and 0.97 , respectively. Moreover, Hypothesis 11, which posits that PEOU has a positive impact on PU was supported and the empirical results provided a strong support for this hypothesis with positive path coefficients 0.35 .

\section{Conclusion}

The use of online banking is expected to grow; however, as there are already several millions of active users worldwide, we need to shift the focus of research towards customer satisfaction and customer loyalty (Yoon, 2010; Mäenpää et al., 2008). The current study has identified several significant factors impacting customer attitudes towards online banking acceptance in the Khorramabad commercial banks including, quality of Internet connection, trust, social influence, resistance to change, awareness of online banking services and its benefits and computer selfefficacy. The results of the $\mathrm{R}^{2}$ have shown some relationships between the Attitude towards using (ATT) and Adoption Intention (AI) has been calculated as 0.94 . The implication is that Attitude towards using online banking has been a critical factor in causing customers Adoption online banking. Therefore Khorramabad commercial banks need to encourage customers by using various types of advertising media such as leaflets and brochures, SMS messages through mobile phones and e-mail. This will result in the widespread promotion of the services to a wider audience and educate potential customers about the benefits of online banking as the service is quite new to many customers. Generally, the increased availability of broadband connection throughout the country would lead to greater adoption of online banking, since the infrastructure plays an important part in limiting adoption rates by Khorramabad customers. Overall, widespread usage of online banking in Khorramabad promising practice, especially if banks can promote the benefits and security features of online banking in the context of increased broadband provision.

\subsection{Research limitations and further research}

The results show that the proposed model has a good explanatory power and confirms its robustness in predicting customers' intentions to use Internet banking. There are several limitations in this research study. The factors selected in this study may not cover all important issues that could influence the adoption of the Internet banking. Therefore, future studies can consider other factors, which might have an influence in the adoption of Internet banking services.

\section{Acknowledgement}

The authors would like to thank the anonymous referees for constructive comments on earlier version of this paper.

\section{References}

Al-Somali, S. A., Gholami, R., \& Clegg, B. (2009). An investigation into the acceptance of online banking in Saudi Arabia. Technovation, 29(2), 130-141.

Alagheband, P. (2006). Adoption of electronic banking services by Iranian customers. Master's thesis, Luela University of Technology, Iran.

Agarwal, R., \& Prasad, J. (1999). Are individual differences germane to the acceptance of new information technologies? Decision Science, 30(2), 361-391.

Ajzen, I. (1991). The theory of planned behaviour. Organisational Behaviour and Human Decision Processes, 50, 179-211. 
Al-Gahtani, S. (2001). The applicability of TAM outside North America: an empirical test in the United Kingdom. Information Resource Management Journal, 14(3), 37-46.

Alsajjan, B., \& Dennis, C. (2010). Internet banking acceptance model: Cross-market examination. Journal of Business Research, 63(9), 957-963.

Chau, P. Y. K., \& Hu, P. J. (2001). Information Technology Acceptance by Individual Professionals: A Model Comparison Approach. Decision Sciences, 32(4), 699-719.

Lee, M. C. (2009). Factors influencing the adoption of internet banking: An integration of TAM and TPB with perceived risk and perceived benefit. Electronic Commerce Research and Applications, 8(3), 130-141.

Compeau, D. R., \& Higgins, C. A. (1995). Computer self-efficacy: Development of a measure and initial test. MIS quarterly, 189-211.

Daniel, E. (1999). Provision of electronic banking in the UK and the Republic of Ireland. International Journal of Bank Marketing, 17(2), 72-83.

Davis, F.D., Bagozzi, R.P., \& Warshaw, P.R.(1989). User acceptance of computer technology : a comparison of two theoretical models. Management Science, 35(8), 982-1003.

Davis, F. (1989). Perceived usefulness, perceived ease of use, and user acceptance of information technology. MIS Quarterly, 13(3), 319-340.

Fishbein, M., \& Ajzen, I. (1975). Belief, attitudes, intention and behavior: An introduction to theory and research. Reading MA: Addision-Wasely.

Fortin, D. R., Dholakia, R. R., \& Dholakia, N. (2002). Emerging issues in electronic marketing: thinking outside the square. Journal of Business Research, 55(8), 623-627.

Friedman, B., Khan Jr, P. H., \& Howe, D. C. (2000). Trust online.Communications of the $A C M, 43(12), 34-40$.

Gefen, D., \& Straub, D. (2000). The relative importance of perceived ease of use in is adoption: A study of ecommerce adoption. Journal of the Association for Information Systems, 1(8).

Gefen, D. (2000). E-commerce: The role of familiarity and trust. Omega — The International Journal of Management Science, 28, 725-737.

Grewal, D., Iyer, G. R., \& Levy, M. (2004). Internet retailing: enablers, limiters and market consequences. Journal of Business Research, 57(7), 703-713.

Harrison, A. W., \& Rainer, R. K. (1992). The influence of individual differences on skill in end-user computing. Journal of Management Information Systems, 9(1), 93-111.

Howcroft, B., Hamilton, R., \& Hewer, P. ( 2002). Consumer attitude and the usage and adoption of home-based banking in the United Kingdom. The International Journal of Bank Marketing, 20(3), $111-121$.

Huizingh, E. K. (2000). The content and design of web sites: An empirical study. Information \& Management, 37(3), 123-134.

Igbaria, M., Iivari, J., \& Maragahh, H. (1995). Why do individuals use computer technology? $A$ Finnish case study. Information \& Management, 29(5), 227-238.

Karjaluoto, H., Mattila, M., \& Pento, T. (2002). Factors underlying attitude formation towards online banking in Finland. International Journal of Bank Marketing, 20(6), 261-272.

Kalakota, R., \& Robinson, M. (2003). Electronic commerce (pp. 628-634). John Wiley and Sons Ltd.

Kramer, R. M. (1999). Trust and distrust in organizations: Emerging perspectives, enduring questions. Annual Review of Psychology, 50(1), 569-598.

Kuisma, T., Laukkanen, T., \& Hiltunen, M. (2007). Mapping the reasons for resistance to Internet banking: A means-end approach. International Journal of Information Management, 27(2), 75-85.

Levin, T., \& Gordon, C. (1989). Effect of gender and computer experience on attitudes towards computer. Journal of Educational Computing Research, 5(1), 69-88.

Littler, D., \& Melanthiou, D. (2006). Consumer perceptions of risk and uncertainty and the implications for behaviour towards innovative retail services: the case of internet banking. Journal of Retailing and Consumer Services,13(6), 431-443. 
Liu, C., Marchewka, J. T., Lu, J., \& Yu, C. S. (2004). Beyond concern: a privacy-trust-behavioral intention model of electronic commerce. Information \& Management, 42(1), 127-142.

Mäenpää, K., Kale, S. H., Kuusela, H., \& Mesiranta, N. (2008). Consumer perceptions of Internet banking in Finland: The moderating role of familiarity.Journal of retailing and consumer services, 15(4), 266-276.

McKnight, D. H., \& Chervany, N. L. (2002). What trust means in e-commerce customer relationships: an interdisciplinary conceptual typology. International journal of electronic commerce, 6, 35-60.

Morgan, R. M., \& Hunt, S. D. (1994). The commitment-trust theory of relationship marketing. the journal of marketing, 20-38.

Nasri, W., \& Charfeddine, L. (2012). Factors affecting the adoption of Internet banking in Tunisia: An integration theory of acceptance model and theory of planned behavior. The Journal of High Technology Management Research,23(1), 1-14.

Polatoglu, V. N., \& Ekin, S. (2001). An empirical investigation of the Turkish consumers' acceptance of Internet banking services. International Journal of Bank Marketing, 19(4), 156-165.

Ranganathan, C., \& Ganapathy, S. (2002). Key dimensions of business-to-consumer web sites. Information \& Management, 39(6), 457-465.

Rousseau, D. M., Sitkin, S. B., Burt, R. S., \& Camerer, C. (1998). Not so different after all: A crossdiscipline view of trust. Academy of management review, 23(3), 393-404.

Sathye, M. (1999). Adoption of internet banking by Australian consumer: an empirical investigation. International Journal of Bank Marketing, 17 (7), 324-334.

Succi, M.J., \& Walter, Z.D.(1999). Theory of users acceptance of information technologies: an examination of health care professionals. Proceeding of the 32nd Hawaii international conference on system Science (HICSS), pp.1-7.

Szajna, B. (1994). Software evaluation and choice: Predictive evaluation of the technology acceptance instrument. MIS Quarterly, 18(3), 319-324.

Taylor, S., \& Todd, P.A. (1995). Assessing IT usage: the role of prior experience. MIS Quarterly, 19(4), 561-570.

Venkatesh, V., \& Davis, F.D. (1996). A model of the antecedents of perceived ease of use: development and test. Decision Science, 27(3), 451-481.

Venkatesh, V., Morris, M.G., Davis, G.B., \& Davis, F.D. (2003). User acceptance of information technology: towards a unified view. MIS Quarterly, 27(3), 425-478.

Venkatesh, V., \& Morris, M.G.(2000).Why do not men ever stop to ask for directions? Gender, social influence, and their role in technology acceptance and usage behaviour. MIS Quarterly, 24(1), $115-139$.

Wallis, S. (1997). Financial System Inquiry final report: overview. Australian Government Publishing Service.

Wang, Y. S., Wang, Y. M., Lin, H. H., \& Tang, I. (2003). Determinants of user acceptance of internet banking: an empirical study. International Journal of Service Industry Management, 14(5), 501519.

Yoon, C. (2010). Antecedents of customer satisfaction with online banking in China: The effects of experience. Computers in Human Behavior, 26(6), 1296-1304. 